DOI 10.18551/rjoas.2021-11.04

\title{
THE EFFECT OF PROFITABILITY, FIRM SIZE, CAPITAL STRUCTURE AND TAX AVOIDANCE ON FIRM VALUE
}

\author{
Armana I Made Revi*, Purbawangsa Ida Bagus Anom \\ Faculty of Economics and Business, University of Udayana, Bali, Indonesia \\ *E-mail: revi.armana@gmail.com
}

\begin{abstract}
The aim of this research is to analyze and determine the effect profitability, firm size, capital structure and tax avoidance on firm value. The population in this study is the infrastructure sector companies listed on the Indonesia Stock Exchange in 2016-2019 as many as 57 companies. Determination of the sample carried out in this study by using purposive sampling technique. Data were analyzed using multiple linear regression analysis techniques. The results showed that profitability, firm size, capital structure and tax avoidance has a positive and significant effect on firm value in infrastructure sector companies listed on the Indonesia Stock Exchange from 2016-2019. The theoretical implications that can be given from the findings of this study are the higher the profitability, firm size, capital structure and tax avoidance of a company, the firm value will increase and the practical implications are helping company management in increasing firm value and helping investors in determining the right investment decisions, so that it can assess the company has good prospects in the future.
\end{abstract}

\section{KEY WORDS}

Profitability, firm size, capital structure, tax avoidance, firm value.

The firm value can be influenced by several factors such as profitability, firm size, capital structure (Yuanita et al, 2016), and tax avoidance (Wanami and Merkusiwati, 2019). according to Fahad and Busru (2021)defines profitability as, the extent to which the company generates profit from sales and investments of the company. The relationship between profitability and firm value is the higher the company's profitability, the higher the company's efficiency in utilizing company facilities to generate profits and will create higher firm value and can increase shareholder wealth. Return on Assets (ROA), is a ratio used to measure the company's ability to generate profits from investment activities (Sartono, 2010:123). Profitability is measured using Return on Assets (ROA), namely by comparing profit after tax with total assets (Yanti and Darmayanti, 2019). If the company's profitability is good, then stakeholders will see the extent to which the company can generate profits from the company's sales and investment. Companies with good performance will generate profitability that will increase the firm value (Dinah and Darsono, 2017). Increased profitability can be used as one measure in determining the success of a company, the higher the profitability, the better the company's performance. The firm value can also be influenced by the size of the profitability generated by the company, high profitability will provide good company prospects thereby increasing the demand for shares (Suwardika and Mustanda, 2017).

Several studies related to profitability to firm value found results such as those carried out by Yuanita et al, (2016), Sabrin et al, (2016), Kamaliah, (2020), Simanjuntak and Young, (2020) states that profitability has a positive and significant effect on firm value. Thus, companies with high profitability will be able to increase the firm value. The implication is that the company's profit provides information that the company is able to pay more dividends so that the stock price will increase because the company shows a positive signal to pay dividends. Different results are shown by research from (Primary and Wiksuana, 2018) which shows that profitability has a significant negative effect on firm value in consumer goods industrial companies listed on the IDX for the period 2012-2016. This show, the greater the profit obtained from a company does not guarantee an increase in the firm value. Research 
conducted by Fahad and Busru (2021) find the results of the tendency of negative influence of CSR disclosure on corporate profitability and firm value in India; This negative influence is mainly influenced by environmental disclosure scores and social disclosure scores. The detrimental effect of firm profitability and firm value on CSR disclosure was also observed to underline the inverse relationship.

The firm size is the size of a company that can be seen through the amount of equity, sales and total assets of the company. The greater the total assets of the company can illustrate that the company has reached the maturity stage. Companies that are already in the maturity stage, the company already has a positive cash flow and is expected to have profitable aspects in a relatively long period of time. Given that the total firm value's assets is very large and must be normally distributed, the firm size (SIZE) is calculated by means of the natural logarithm of total assets. The higher the firm size will be closely related to the funding decisions that will be applied by the company in order to optimize the firm value. Suwardika and Mustanda, (2017) argues that large companies with large share distributions will also have a small impact on the loss of control from the dominant party over the company, so large companies tend to be more daring to issue new shares to meet company needs than small companies.

Several studies related to firm size on firm value found results such as those conducted by Dang et al, (2019) states that firm size has a positive effect on firm value, research from Hamyat et al, (2017) states that firm size has a significant positive effect on firm value, and research from Andawasatya et al, (2017)also stated that the firm size has a significant positive effect on firm value. A large firm size reflects the higher the firm value. On the other hand, research from Cheryta et al, (2017) states that firm size has a negative and significant effect on firm value mediated by cash holdings. This statement is also supported by research from Sintyana and Artini (2018)which states that firm size has no effect on firm value. Research conducted by Hirdinis, (2019) states that firm size has a significant negative effect on firm value.

Capital structure is defined as $p$ balance or comparison between the amount of longterm debt with its own capital (Septiani and Suaryana, 2018). The optimal capital structure is the capital structure that is expected to produce the lowest weighted average cost of capital so that it will maximize the firm value (Aggarwal and Padhan, 2017). Capital structure can be measured by the Debt to Equity Ratio (DER), which is to compare the company's total debt with the company's total equity (Yanti and Darmayanti, 2019). In general, maximizing firm value is the main goal of every company, because high firm value can increase prosperity for shareholders, can be a strong foundation for companies to run their operations, and be able to bring optimal profits for the company (Nadzirah, 2016). This shows that the determination of capital structure is an important issue for every company.

Research on the effect of capital structure on firm value has been studied previously. Research from Aggarwal and Padhan (2017) states that the capital structure has a significant positive effect on firm value. Research from Hirdinis, (2019)states that capital structure has a positive effect on firm value. On the other hand, research from Hamyat et al, (2017)stated that the capital structure has no effect on the value of the capital structure or the capital structure has a negative effect on the firm value. This statement is also supported by research from Sintyana and Artini (2018) which states that capital structure has no effect on firm value.

Tax is a mandatory contribution that must be paid by the people to the state to be used for the benefit of the general public and the government. The government continues to make efforts to optimize state revenues from taxes. Tax is one of the most important sources of state income and which aims to improve the welfare and prosperity of the people, while taxes for companies are a burden. In the event that the company will carry out tax planning practices which include tax avoidance, which is an effort to minimize the tax burden that is carried out legally without violating existing tax regulations (Cahyono, 2016). In carrying out tax avoidance practices, there are risks that are borne due to errors in tax avoidance, namely the loss of investor confidence and the burden of high tax penalties that can reduce the firm value (Yuyetta and Winasis, 2016). 
Research conducted by Kurniawan and Syarifuddin (2017), Wanami and Merkusiwati (2019), Wester and Hutabarat (2020), stated that tax avoidance has a positive and significant effect on firm value. This shows that the higher the tax avoidance by the company will increase the firm value because it can improve the welfare of investors, by transferring wealth from the government to shareholders. While the research conducted by Nafti et al, (2020)states that tax avoidance has a negative or indirect effect on firm value. Research conducted by Nafti et al, (2020)highlights the moderating effect of family management on the relationship between tax avoidance and firm value. Research conducted by Santa and Rezende, (2016), Hanif, (2019), Eka and Muid, (2017)which states that tax evasion has a negative effect on firm value. Research conducted by Park et al, (2016)stated that high managerial ability reduces the negative relationship between tax avoidance and firm value. These findings indicate that managerial skills affect corporate tax avoidance behavior.

\section{LITERATURE REVIEW AND HYPOTHESES DEVELOPMENT}

Profitability is a measure of the company's ability to earn profits. Increased profitability can be used as one measure in determining the success of a company, the higher the profitability, the better the company's performance. Companies with high profitability will be able to increase the firm value. The implication is that the company's profit provides information that the company is able to pay more dividends so that the stock price will increase because the company shows a positive signal to pay dividends. according to Lambey, (2021)An investment is said to be an investment if it can make investors richer. In other words, the prosperity of investors becomes greater after investing. The higher the company's ability to generate profits, the greater the return expected by investors so that the firm value is getting better.

Yuanita et al, (2016)in his research found that profitability has a positive effect on firm value, so companies with high profitability will be able to increase firm value. The implication is that the company's profit provides information that the company is able to pay more dividends. This finding is supported by Sabrin et al, (2016), Kamaliah (2020), Simanjuntak and Young (2020)which states that profitability has a positive effect on firm value.

H1: Profitability has a positive and significant effect on firm value.

Firm size is a measure of the value of equity, total sales, or the total value of assets owned by the company (Yuanita et al, 2016).Dang et al, (2019) states that large companies will tend to diversify more than small companies. Therefore, the possibility of failure or bankruptcy of large companies will be smaller. Firm size can be seen using several proxies, such as company performance, total capital, total assets, total equity, or company share price. A bigger firm size means everything about the company is better. So, bigger firm size means bigger firm value too. This view is supported by Andawasatya et al, (2017). However, Hirdinis (2019) shows that the higher the firm size, the more likely the company is to experience bigger problems.

Research conducted by Dang et al, (2019)states that firm size has a significant positive effect on firm value. This research is also supported by research from Hamyat et al (2017), Andawasatya et al, (2017) also states that firm size has a significant positive effect on firm value. A large firm size reflects the higher the firm value.

H2: Firm size has a positive and significant effect on firm value.

Umdiana and Claudia (2020)explain the relationship between capital structure and firm value through the Tradeoff Theory. They explain that companies trade the tax benefits of debt financing for the problems that arise from potential bankruptcy. Capital structure theory explains the effect of capital structure on firm value. Firm value can be interpreted as the expected shareholder investment value (equity market price) and or the total firm value expectation (equity market price plus the market value of debt or the expected asset market price) (Hirdinist, 2019). The capital structure is a permanent expenditure which reflects the balance between long-term debt and own capital. The capital structure is a balance of the amount of short-term debt that is permanent, long-term with preferred stock and common stock (Aggarwal and Padhan, (2017). 
According to research from Aggarwal and Padhan (2017) capital structure has a significant positive effect on firm value so that the optimal capital structure can increase firm value. The implication is that the optimal capital structure is a comparison of the use of funds from equity and debt. This research is also supported by research from Hirdinis (2019) states that capital structure has a positive effect on firm value.

H3: Capital structure has a positive and significant effect on firm value.

Tax avoidance according to Wijaya and Bernawati (2021)Tax avoidance is an effort to avoid tax which is carried out in a legal way because it tends to take advantage of the weaknesses contained in the tax laws and regulations themselves to reduce the amount of tax payable. Information on high net income as a result of tax avoidance activities is expected to be a positive signal for investors so that it has a positive impact on the firm value which is reflected in the increase in the value of its shares in the capital market. Tax avoidance can be measured by Effective Tax Rates (ETR), as in research conducted by Wanami and Merkusiwati (2019).

This research is supported by research from Wanami and Merkusiwati, (2019)states that tax avoidance has a positive effect on firm value. This shows that the higher the tax avoidance by the company will increase the firm value because it can improve the welfare of investors, by transferring wealth from the government to shareholders.

H4: Tax avoidance has a positive and significant effect on firm value.

\section{METHODS OF RESEARCH}

The scope of this research includes research locations, namely companies engaged in the infrastructure sector which is listed on the Indonesia Stock Exchange in 2016-2019. The scope of this research also examines the effect of profitability, firm size, capital structure and tax avoidance on firm value.

The population in this study is the infrastructure sector companies listed on the Indonesia Stock Exchange in 2016-2019 as many as 57 companies. Determination of the sample carried out in this study by using a purposive sampling technique where the sample is selected from a population of companies registered in the infrastructure sector that meets several criteria. The criteria are as follows:

- Infrastructure company listed on the Indonesia Stock Exchange in 2016-2019;

- Companies that publish annual financial reports for the 2016 - 2019 period in a row and have complete information regarding Profitability, Firm size, Capital Structure, Tax Avoidance and Firm value;

- The company did not experience any losses during the 2016-2019 observation period.

This study uses a data collection method, namely the non-participant observation method in which the researcher obtains data by making observations without having to be directly involved with the activities of the people or phenomena being observed, and only as an independent observer. This research method obtains data through data collection carried out by observing, recording, and studying descriptions from books, journals, theses and accessing the Indonesia Stock Exchange website through www.idx.co.id. The data is obtained in the form of annual reports of companies listed in the infrastructure sector using 4 years of data from companies that are sampled.The data analysis used in this study is multiple linear regression analysis.

\section{RESULTS AND DISCUSSION}

Model Feasibility Test. The stated value is used to test the feasibility of the analytical model (where a number of $X$ variables affect the $Y$ variable) provided that a good profitability number to be used as a regression model must be $<0.05$. This value can be seen in the Sig column. if the significance $<0.05$, then the analysis model is considered feasible. If the significance value is $>0.05$, then the analysis model is considered not feasible. 
Table 1 - F Test Results

\begin{tabular}{llllll}
\hline Model & Sum of Squares & df & Mean Square & F & Sig. \\
\hline \multirow{2}{*}{1} & $1,176,003$ & 4 & 294001 & 41.826 & $.000 a$ \\
\cline { 2 - 6 } & 583,421 & 83 & 7.029 & & \\
\hline
\end{tabular}

Source: Secondary Data, 2021.

$F$ test results shows that the significance value of $P$ value is 0.000 which is smaller than $=0.05$, this means that the model used in this study is feasible. This result means that all independent variables, namely profitability, firm size, capital structure and tax avoidance are able to predict or explain the phenomenon of the value of infrastructure sector companies listed on the Indonesia Stock Exchange in 2016-2019. This means that the model can be used for further analysis or in other words the model can be used for projecting because the results of goodness of fit are good with a significance value of $P$ value of 0.000 .

Coefficient of Determination (adjusted $R^{2}$ ). The value of the coefficient of determination is between zero and one. A small value of R2 means that the ability of the independent variables in explaining the variation of the dependent variable is very limited. The results of the coefficient of determination test can be seen in Table 2.

Table 2 - Coefficient of Determination Test (Adjusted $\mathrm{R}^{2}$ )

\begin{tabular}{lllll}
\hline Model & $\mathrm{R}$ & $\mathrm{R}$ Square & Adjusted R Square & Std. Error of the Estimate \\
\hline 1 & $.818 \mathrm{a}$ & .668 & .652 & 265.126 \\
\hline
\end{tabular}

Source: Secondary Data, 2021.

In Table 3 it can be seen that the results of the coefficient of determination test with an adjusted $\mathrm{R} 2$ value of 0.652 , this means that $65.2 \%$ of the variation in earnings quality is influenced by variations in profitability (X1), firm size (X2), capital structure (X3), tax avoidance (X4) as an influencing variable. The remaining $34.8 \%$ is influenced by other factors outside the model.

Multiple Regression Analysis Results. Based on the data processing process with SPSS, the results are presented in Table 3 below.

Table 3 - Multiple Regression Test Results

\begin{tabular}{|c|c|c|c|c|c|}
\hline \multirow{2}{*}{ Model } & \multicolumn{2}{|c|}{ Unstandardized Coefficients } & \multirow{2}{*}{$\begin{array}{l}\text { Standardized Coefficients } \\
\text { Beta }\end{array}$} & \multirow{2}{*}{$\mathrm{t}$} & \multirow{2}{*}{ Sig. } \\
\hline & B & Std. Error & & & \\
\hline \multirow{5}{*}{1} & $-4,328$ & 1,860 & & -2.326 & .022 \\
\hline & 1,929 & .391 & .356 & 4.936 & .000 \\
\hline & .350 & .118 & .260 & 2,978 & .004 \\
\hline & 1,000 & .313 & .222 & 3,200 & .002 \\
\hline & .414 & .078 & .463 & 5.303 & .000 \\
\hline
\end{tabular}

Source: Secondary Data, 2021.

Based on the data in Table 3, the regression equation can be arranged as follows:

$$
Y=+1 X 1+2 X 2+3 X 3+4 X 4
$$

The effect of profitability on firm value. Shows the t value of 4.936 with a t significance of 0.000 which is smaller than the real level $(\alpha)$ used, which is 0.05 . These results indicate that profitability has a positive effect on firm value; this indicates that profitability has a positive effect on firm value so that $\mathrm{H} 1$ is accepted.

The first hypothesis in this study shows that profitability has a positive and significant effect on firm value. The results of this study prove that profitability has a positive and significant effect on firm value. Companies with high profitability will be able to increase the firm value. Profitability obtained by a company will affect the amount of dividends to be paid to shareholders. If the company earns a large amount of profit, the ability to pay dividends 
will also be greater. This shows that the amount of dividends can affect the firm value. The implication is that the profit earned by the company provides information that the company is able to pay more dividends so that the stock price will increase because the company shows a positive signal to pay dividends. Based on this, the results of this study support the signaling theory which states that the larger the dividends given will give a positive signal to investors. In addition, the higher the company's ability to generate profits, the greater the return expected by investors so that the firm value is getting better.

This finding is consistent with the results of the research proposed by Sabrin et al, (2016), Kamaliah (2020), Simanjuntak and Young (2020)where the results of their research stated that profitability had a positive and significant effect on firm value. It can be concluded that the increase in profitability can be used as one measure in determining the success of a company, the higher the profitability, the better the company's performance. Companies with high profitability will be able to increase the firm value.

The effect of firm size on firm value. Shows the $t$ value of 2,978 with a significance of $t$ of 0.004 which is smaller than the real level ( $\alpha$ ) used, which is 0.05 . These results indicate that firm size has a positive effect on firm value; this indicates that firm size has a positive effect on firm value so that $\mathrm{H} 2$ is accepted.

The second hypothesis in this study shows that firm size has a positive and significant effect on acceptable firm value. The results of this study prove that firm size has a positive and significant effect on firm value, where the more positive the value of the firm size, the more positive the firm value will be. This can explain that a company with a high size will be easier to gain the trust of investors because a company with a larger size will be considered too large to go bankrupt, so that with a high firm size it is relatively easier to increase the firm value.

This finding is consistent with the results of research conducted by Dang et al, (2019), Hamyat et al (2017), Andawasatya et al, (2017)where the results of their research stated that firm size had a positive and significant effect on firm value. It can be concluded that large companies will tend to diversify more than small companies. Therefore, the possibility of failure or bankruptcy of large companies will be smaller. Firm size can be seen using several proxies, such as company performance, total capital, total assets, total equity, or company share price. A bigger firm size means everything about the company is better. So, bigger firm size means bigger firm value too.

The Effect of capital structure on firm value. Shows the $t$ value of 3.200 with a significance of $t$ of 0.002 which is smaller than the real level $(\alpha)$ used, which is 0.05 . These results indicate that capital structure has a positive effect on firm value; this indicates that capital structure has a positive effect on firm value so that $\mathrm{H} 3$ is accepted.

The third hypothesis in this study shows that capital structure has a positive and significant effect on firm value. The results of this study prove that the capital structure has a positive and significant effect on firm value. The more positive the value of the capital structure, the more positive the firm value will be.

One of the decisions that must be taken to increase the firm value is the funding decision, where the company will determine the best capital structure to achieve company goals. The amount of use of internal and external funds will affect the firm value, where internal funds come from retained earnings and external funds come from debt. So that it can be interpreted that the higher the value of debt (capital structure) can increase the firm value. This shows that if the company uses more and more long-term debt to finance its assets, it can increase the firm value. In addition, the policy of increasing debt is a positive signal for investors and affects the firm value. For companies, the existence of debt can help to control the free and excessive use of cash funds by management. This increase in control can increase the firm value which is reflected in the increase in stock prices.

This finding is consistent with the results of previous research conducted by Aggarwal and Padhan (2017), Hirdinis (2019), where the results of their research found that there was a positive and significant relationship between the capital structure variable and firm value. It can be concluded that the greater the capital structure available in a company, the firm value 
will increase. The optimal capital structure is a comparison of the use of funds from equity and debt.

The Effect of tax avoidance on firm value. Shows a t value of 5.303 with a t significance of 0.000 which is smaller than the real level $(\alpha)$ used, which is 0.05 . These results indicate that tax avoidance has a positive effect on firm value. This indicates that tax avoidance has a positive effect on firm value so that $\mathrm{H} 4$ is accepted.

The fourth hypothesis in this study shows that tax avoidance has a positive and significant effect on firm value. The results of this study indicate that tax avoidance has a positive and significant effect on firm value. The more positive the value of tax avoidance, the more positive the firm value will be.

This finding is consistent with the results of research proposed by Kurniawan and Syarifuddin (2017), Wanami and Merkusiwati (2019), Wester and Hutabarat (2020), where their research results state that tax avoidance has a positive and significant effect on firm value. It can be concluded that, the greater the available tax avoidance, the better the resulting firm value. Tax avoidance, if defined more broadly than to increase profits, is also expected to increase firm value. Information on high net income as a result of tax avoidance activities is expected to be a positive signal for investors so that it has a positive impact on the firm value as reflected in the increase in the value of its shares in the capital market. This shows that the higher the tax avoidance by the company will increase the firm value because it can improve the welfare of investors.

\section{CONCLUSION}

First, the results of this study state that profitability has a positive and significant effect on firm value. Based on these findings, the results of this study can strengthen the theory used in the study, namely signaling theory and capital structure theory and enrich the research conducted by Yuanita (2016), Sabrin (2016), Kamaliah (2017), Simanjuntak (2020), and Muda (2020).

Second, the results of this study state that firm size has a positive and significant effect on firm value. Based on these findings, the results of this study can strengthen the theory used in the research, namely signaling theory and capital structure theory, as well as enrich the research conducted by Dang, et al (2019), Yuanita (2016), Hamyat (2017), and Andawasatya (2017).

Third, the results of this study state that the capital structure has a positive and significant effect on firm value. Based on these findings, the results of this study can strengthen the theories used in the research, namely signaling theory and capital structure theory, as well as enrich the research conducted by Aggarwal and Padhan (2017) and Hirdinis (2019).

Fourth, the results of this study state that tax avoidance has a positive and significant effect on firm value. Based on these findings, the results of this study can strengthen the theory used in the study, namely signaling theory and capital structure theory, as well as enriching the research conducted by Kurniawan and Syarifuddin (2017), Wanami and Merkusiwati (2019), Wester and Hutabarat (2020).

This study proves that profitability, firm size, capital structure and tax avoidance must be improved so as to increase firm value. This research can assist company management in increasing the firm value and assist investors in determining the right investment decisions, so that they can assess the company as having good prospects in the future.

Further research is expected to expand the research sample by not only researching one sector but also developing research using all sectors listed on the Indonesia Stock Exchange.

\section{RESEARCH LIMITATIONS}

This study still uses a limited sample of companies in the infrastructure sector listed on the Indonesia Stock Exchange, so that further research can expand the scope of research to 
other sectors. This research still has a limited time or research period, which is four years. Future research is expected to increase the time span of the research to enrich empirical studies on this research topic.

\section{REFERENCES}

1. Aggarwal, D., Padhan, P. C. 2017. Impact Of Capital Structure On Firm Value: Evidence From Indian Hospitality Industry. Theoretical Economics Letters. Vol.7, pp. 982-1000.

2. Akhmadi, A., Prasetyo, A. R. 2018. Profitabilitas, Rasio Solvabilitas Dan Harga Saham; Studi Empirik Pada Perusahaan Subsektor Batubara Yang Terdaftar Di Bursa Efek Indonesia Periode 2010-2014. Jurnal Riset Akuntansi Terpadu. Vol.11, No.1, pp.61-71.

3. Andawasatya, R., Indrawati, N. K., Aisjah, S. 2017. The Effect Of Growth Opportunity, Profitability, Firm Size To Firm Value Through Capital Structure (Study At Manufacturing Companies Listed On The Indonesian Stock Exchange). Imperial Journal Of Interdisciplinary Research. Vol.3, No.2, pp. 1887-1894.

4. Brigham., Houston. 2014. Essentials Of Financial Management. $11^{\text {th }}$ Edition.. Ali Akbar Yulianto (Penerjemah). Dasar-dasar Manajemen Keuangan. Jakarta: Penerbit Salemba empat.

5. Cahyono, D. D. 2016. Pengaruh Komite Audit, Kepemilikan Institusional, Dewan Komisaris, Ukuran Perusahaan (Size), Leverage (DER) dan Profitabilitas (ROA) Terhadap Tindakan Penghindaran Pajak (Tax Avoidance) Pada Perusahaan Perbankan Yang Listing BEI Periode Tahun 2011-2013. Journal of Accounting. Vol.2, No.2, pp.1-10.

6. Cheryta, A. M., Moeljadi., Indrawati, N. K. 2017. The Effect Of Leverage, Profitability, Information Asymmetry, Firm Size On Cash Holding And Firm Value Of Manufacturing Firms Listed At Indonesian Stock Exchange. International Journal Of Research In Business Studies And Management. Vol.4, No.4, pp. 21-31.

7. Choriliyah, S., Sutanto, H. A., Hidayat, D. S. 2016. Reaksi Pasar Modal Terhadap Penurunan Harga Bahan Bakar Minyak (BBM) Atas Saham Sektor Industri Transportasi Di Bursa Efek Indonesia. Journal Of Economic Education. Choriliyah, S., Sutanto, H. A., Hidayat, D. S. 2016. Reaksi Pasar Modal Terhadap Penurunan Harga Bahan Bakar Minyak (BBM) Atas Saham Sektor Industri Transportasi Di Bursa Efek Indonesia. Journal Of Economic Education. Vol.5, No.1, pp.1-10.

8. Dang, Hung Ngoc., Vu, Van Thi Thuy., Ngo, Xuan Thanh., Hoang, Ha Thi Viet. 2019. Study The Impact Of Growth, Firm Size, Capital Structure, And Profitability On Enterprise Value: Evidence Of Enterprises In Vietnam. Journal Of Corporate Accounting \& Finance. Vol.30, No.1 pp.144-160.

9. Dewi, P. P. A. R. 2021. Pengaruh Corporate Social Responsibility Pada Nilai Perusahaan Dengan Profitabilitas Dan Leverage Sebagai Pemoderasi. Thesis. Fakultas Ekonomi Dan Bisnis Universitas Udayana. Vo. 23, No.2, pp. 1470-1494.

10. Dinah, A. F., Darsono. 2017. Pengaruh Tata Kelola Perusahaan, Profitabilitas, Dan Penghindaran Pajak Terhadap Nilai Perusahaan. Jurnal Akuntansi Diponegoro. Vol.6. No.3. pp 1-15.

11. Eka, I., Muid, D. 2017. Analisis Pengaruh Tata Kelola Perusahaan Dan Penghindaran Pajak Terhadap Nilai Perusahaan. Diponegoro Journal Of Accounting. Vol.6. No.3, pp. 18.

12. Fahad, P., Busru, S. A. 2021. CSR Disclosure And Firm Performance: Evidence From An Emerging Market. Corporate Governance (Bingley). International Journal of Business in Society, Vol. 21, No.4, pp. 553-568.

13. Ghozali, I. 2018. Aplikasi Analisis Multivariate Dengan Program IBM SPSS 25. Semarang: Badan Penerbit Universitas Diponegoro.

14. Hamyat, Hasbi., Sarita, Buyung., Hasbudin, Sujono. 2017. The Effect Of Firm Size And Diversification On Capital Structure And Firmvalue (Study In Manufacturing Sector In Indonesia Stock Exchange). The International Journal Of Engineering And Science. Vol.6, No 6, pp.50-61.

15. Hanif. 2019. Analisis Pengaruh Praktik Penghindaran Pajak Terhadap Nilai Perusahaan: 
Transparansi Informasi Sebagai Variabel Pemoderasi. Diponegoro Journal Of Accounting. Vol.8, No.3, pp. 1-12.

16. Hirdinis, M. 2019. Capital Structure And Firm Size On Firm Value Moderated By Profitability. International Journal Of Economics And Business Administration. Vol.7, No.1, pp. 174-191.

17. Juliantika, N., Dewi, M. 2016. Pengaruh Profitabilitas, Ukuran Perusahaan, Likuiditas, Dan Risiko Bisnis Terhadap Struktur Modal Pada Perusahaan Property Dan Realestate. E-Jurnal Manajemen Unud. Vol.5, No.7, pp. 4161-4192.

18. Kamaliah. 2020. Disclosure Of Corporate Social Responsibility (Csr) And Its Implications On Company Value As A Result Of The Impact Of Corporate Governance And Profitability. International Journal Of Law And Management. Vol.62, No.4, pp. 339-354.

19. Kurniawan, Syafruddin. 2017. Pengaruh Penghindaran Pajak Terhadap Nilai Perusahaan Dengan Variabel Moderasi Transparansi. Diponegoro Journal Of Accounting. Vol.6, No.44, pp. 1-10.

20. Lambey, R. 2021. The The Effect Of Profitability, Firm Size, Equity Ownership And Firm Age On Firm Value (Leverage Basis): Evidence From The Indonesian Manufacturer Companies. Archives Of Business Research. Vol.9, No.1, pp.129-139.

21. Lubis, I. L., Sinaga, B. M., Sasongko, H. 2017. Pengaruh Profitabilitas, Struktur Modal, Dan Likuiditas Terhadap Nilai Perusahaan. Jurnal Aplikasi Bisnis Dan Manajemen. Vol.3. No.3, pp. 458-465.

22. Mayangsari, R. 2018. Pengaruh Struktur Modal, Keputusan Investasi, Kepemilikan Manajerial, Dan Komite Audit Terhadap Nilai Perusahaan Sektor Aneka Industri Yang Listing Di Bursa Efek Indonesia Periode 2012-2016. Jurnal IImu Manajemen. Vol.6, No.4, pp. 477-485.

23. Mubyarto, N. 2020. The Influence Of Profitability On Firm Value With Capital Structure As The Mediator. Jurnal Economia. Vol. 16, No. 2, pp. 184-199.

24. Nadzirah., Yudiaatmaja, Cipta. 2016. Pengaruh Ukuran Perusahaan Dan Profitabilitas Terhadap Struktur Modal. e-Juornal Bisma Undiksha. Vol.4. pp. 1-10.

25. Nafti, O., Kateb, I., Masghouni, O. 2020. Tax Evasion, Firm's Value And Governance: Evidence From Tunisian Stock Exchange. Journal Of Financial Crime. Vol.27, No.3, pp. 781-799.

26. Oktaviani, Susanti, Sunarto,Udin. 2019. The Effect Of Profitability, Tax Avoidance And Information Transparency On Firm Value: An Empirical Study In Indonesia. International Journal Of Scientific And Technology Research. Vol.8, pp. 3777-3780.

27. Park, Joonho., Ko, Chang Youl., Jung, Hoon., Lee, Yong Seok. 2016. Managerial Ability And Tax Avoidance: Evidence From Korea. Asia-Pacific Journal Of Accounting And Economics. Doi: 10.1080/16081625.2015.1017590.

28. Pramana, I. G. N. A. D., Mustanda, I. K. 2016. Pengaruh Profitabilitas Dan Size Terhadap Nilai Perusahaan Dengan Csr Sebagai Variabel Pemoderasi. E-Jurnal Manajemen Unud. Vol.5. No.1. pp 561-594.

29. Pratama, Angga A. B., Wiksuana, I. G. B. 2018. Pengaruh Firm Size Dan Profitabilitas Terhadap Nilai Perusahaan Dengan Struktur Modal Sebagai Variabel Mediasi. E-Jurnal Ekonomi Dan Bisnis Universitas Udayana. Vol.7, No.5, pp. 1289-1318.

30. Rahayu, Sri Mangesti., Suhadak., Saifi, Muhamad. 2020. The Reciprocal Relationship Between Profitability and Capital Structure and its Impacts on The Corporate Values of Manufacturing Companies in Indonesia. International Journal of Productivity and Performance Management. Vol.69, No.2, pp.236-251.

31. Rezy, F. 2020. Indeks Harga Saham Gabungan (IHSG). Oke Finance.(online), https://economy.okezone.com.

32. Rudangga, I. G. N. G., Sudiarta, G. M. 2016. Pengaruh Ukuran Perusahaan, Leverage, Dan Profitabilitas Terhadap Modal Intelektual Perusahaan. E-Jurnal Manajemen Universitas Udayana. Vol.5, No.7, pp. 4394-4422.

33. Sabrin, Buyung Sarita, Dedy Takdir .S, S. 2016. The Effect Of Profitability On Firm Value In Manufacturing Company At Indonesia Stock Exchange. Experimental Cell Research. Vol.5, No.10, pp.81-89. 
34. Santa, S. L. L., Rezende, A. J. 2016. Corporate Tax Avoidance And Firm Value: From Brazil Elision Fiscal Y Valor De La Empresa: Evidencia En Brasil. Revista Contemporânea De Contabilidade, Issn 2175-8069, Ufsc, Florianopolis, Vol. 13, No. 30, pp. 114-133.

35. Simanjuntak, S., Muda, I. 2020. The Effect Of Corporate Social Responsibility (Csr) On Corporate Value With Profitability As Intervening (Case Study Company In Sri Kehati Index Listed In Bei 2009 - 2018). International Journal Of Research And Review. Vol.7, No.5, pp.310-319.

36. Sintyana, I. P. H., Artini, L. G. S. 2018. Pengaruh Profitabilitas, Struktur Modal, Ukuran Perusahaan Dan Kebijakan Dividen Terhadap Nilai Perusahaan. E-Jurnal Manajemen Universitas Udayana. Sintyana, I. P. H., Artini, L. G. S. 2018. Pengaruh Profitabilitas, Struktur Modal, Ukuran Perusahaan Dan Kebijakan Dividen Terhadap Nilai Perusahaan. E-Jurnal Manajemen Universitas Udayana. Vol.8, No.2, pp.7717-7745.

37. Sugiyono, D. 2018. Metode Penelitian Kuatintatif, Kualitatif, dan R \& D. Edisi kedua. Bandung: Penerbit Alfabeta.

38. Suwardika, I. N., Mustanda, I. K. 2017. Pengaruh Leverage, Ukuran Perusahaan, Pertumbuhan Perusahaan Dan Profitabilitas Terhadap Nilai Perusahaan (Perusahaan Properti Yang Terdaftar Di Bursa Ffek Indonesia). E-Jurnal Manajemen Universitas Udayana.Vol.6, No.3, pp. 1248-1277.

39. Septiani, Nita N. P., Suaryana, I. G. N. A. 2018. Pengaruh Profitabilitas, Ukuran Perusahaan, Struktur Aset, Risiko Bisnis dan Likuiditas Pada Struktur Modal. E-Jurnal Akuntansi Universitas Udayana. Vol.22, No.3, pp.1682-1710.

40. Umdiana, N., Claudia, H.2020.Analisis Struktur Modal Berdasarkan Trade Off Theory.Jurnal Akuntansi :Kajian IImiah Akuntansi. Vol. 7, No.1,pp.52-70.

41. Wahyuningsih, P., Widowati, M. 2016. Analisis ROA dan ROE Terhadap Nilai Perusahaan Dengan Corporate Social Responsibility Sebagai Variabel Moderating (Studi Pada Perusahaan Bumn Yang Terdaftar Di Bei Periode 2010-2013). Jurnal Stie Semarang. Vol.8, No.3, pp.83-102.

42. Wanami P, N. W. S. P., Merkusiwati, N. K. L. A. 2019. Pengaruh Penghindaran Pajak Pada Nilai Perusahaan Dengan Kebijakan Hutang Sebagai Variabel Pemoderasi. EJurnal Akuntansi. Vol.27, No.1, pp. 446-474.

43. Wester, Hutabarat. 2020. The Influence Of Capital Structure On Property and Real Estate Companies Value with Tax Avoidance As Mediation Variables. Jurnal IImiah Akuntansi. Vol.4, No.4, pp.381-391.

44. Wijaya, M., Bernawati, Y. 2021. The Effect Of Intervening Tax Avoidance On Leverage On Firm Value. E-Jurnal Akuntansi. Vol.31, No.31, pp.1-14.

45. Wikartika, I., Fitriyah, Z. 2018. Pengujian Trade Off Theory Dan Pecking Order Theory Di Jakarta Islamic Index. Bisma (Bisnis Dan Manajemen). Vol.10, No.2, pp.90-101.

46. Yanti, I. G. A. D. N., Darmayanti, N. P. A. 2019. Pengaruh Profitabilitas, Ukuran Perusahaan, Struktur Modal, Dan Likuiditas Terhadap Nilai Perusahaan Makanan Dan Minuman. E-Jurnal Manajemen Universitas Udayana. Vol.8, No.4, pp.2297-2324.

47. Yuyetta, Afri E. N., Winasis, S. 2016. Pengaruh Gender Diversity Eksekutif Terhadap Nilai Perusahaan, Tax Avoidance Sebagai Variabel Intervening: Studi Kasus Pada Perusahaan Pertambangan Yang Terdaftar Di BEI Tahun 2012-2015. Diponegoro Journal Of Accounting. Vol.6, No.1, pp.1-14.

48. Yuanita, Missy., Budiyanto,. Riyadi. 2016. Influence Of Capital Structure, Size And Growth On Profitability And Corporate Value. International Journal Of Business And Finance Management Research. Vol.4, pp. 80-110.

49. Zuhroh, I. 2019. The Effects Of Liquidity, Firm Size, And Profitability On The Firm Value With Mediating Leverage. Kne Social Sciences. Vol.2019, pp.203-230. 